\title{
Recurring Outbreaks of Fowl Pox in a Poultry Farm in Nsukka, Southeast Nigeria
}

\author{
Okwor, Emmanuel C*.,Eze, Didacus C and Chah, Kennedy F. \\ Department of Veterinary Pathology and Microbiology,University of Nigeria, Nsukka
}

\begin{abstract}
This paper reports on recurring outbreaks of fowl pox in a particular pen present in a poultry farm located at Nsukka, Southeast Nigeria. The outbreaks were seen in one batch of white cockerel and two batches of brown layers. Reduced egg production, weight loss, nodular lesions on the combs, wattles and eyelids, and diphtheritic lesions in the mucous membranes of the oral cavity characterized the disease. At post mortem, a characteristic whitish cheesy material conforming to the shape of the cornea was common in the severe outbreak in layers, but absent in the cockerels and the mild outbreak in layers. No bacteria were isolated from the matrix of the cheesy material while Staphylococcusaureus and Escherichia coli were isolated from the surface of the cheesy material and the ocular swab. The report also showed the importance of vaccination in control of the disease. There was enteritis and soiled vents in the cases examined. Biosecurity measures combined with vaccinations were suggested indispensible for the control of the disease in Nigeria.
\end{abstract}

Keywords: Fowl pox; poultry farm; white cockerels; brown layers

\section{Introduction}

Pox is a viral disease seen in domestic and wild birds (Tripathy and Reed, 2003; Silva et al., 2009). The etiologic agent, Fowl poxvirus is classified in the genus, Avipoxvirus, subfamily Chordopoxvirinae of the family Poxviridae (Fauquetet al., 2005). Poxviruses are large, double stranded DNA viruses that multiply in the cytoplasm of the host cell. They are the largest animal virus, with a brick shape, ranging in size from 200 to $400 \mathrm{~nm}$ long and 170 to 200nm wide (Chambers et al., 2009).Avian pox has been described in chickens, pigeons, ostriches, quails, pheasants, canaries, and a lot of other avian species (Afonsoet al., 2000; Silva et al., 2009). Two forms of the disease are associated with different routes of infection (Afonsoet al., 2000). The disease can occur as a mild cutaneous form with low mortality or as a diphtheritic form which can be more severe or both (Ariyoshiet al., 2003; Tripathy and Reed, 2003; Adebajoet al., 2012). The disease is transmitted through direct contact or by mechanical vectors, primarily mosquitoes and other flies (Adebajoet al., 2012). The disease is characterized by the development of discrete nodular proliferative lesions in the non feathered areas like the combs, wattles, eyelids, legs and mucous membranes of the oral cavity, upper respiratory and digestive systems (Mockett, 1996; Medina et al., 2004; Hsieh, 2005). Diagnosis of fowl pox is straightforward and can be made onthe basis of clinical signs and lesions (Mockett, 1996), while confirmation is by histopathology or immunology or virus isolation (Tripathy, 1993; Todeseet al., 2007; OIE, 2008).

Fowl pox is globally distributed and is an economically important disease of poultry (Pledger, 2005) but the use of vaccines has reduced the incidence (Naguet al., 1990). In Nigeria, commercial poultry flocks are vaccinated against the disease while the indigenous free range chickens are not. Vaccination of the commercial flocks has helped to reduce the losses associated with the disease in this population of chickens (Odoyael al., 2006; Okworet al., 2012). Because of this, emphases are very often laid on the control of other more economically important diseases like Newcastle disease and Infectious Bursal disease. This has lead to the occasional non institution of adequate prophylactic measures against fowl pox with resultant sporadic outbreak of the disease. Moreover, the disease is quite common among the indigenous chickens which are mostly free range scavengers (Adebajoet al., 2012) and are predominantly unvaccinated against the disease. These birds therefore play important epidemiological role in the maintenance and transmission of the virus to the commercial flocks. This paper reports the ubiquitous nature of the virus in the production of recurring infection in a poultry farm located in Nsukka, a University town in the tropical South Eastern part of Nigeria. It also reports an unusual lesion associated with an outbreak.

\section{Experimental design}

\section{Material and Methods}

Three case outbreaks of fowl pox in a particular pen sited in a poultry farm located in Nsukka, South East Nigeria were followed. Thedisease was confirmed by agar gel immunodiffusion test (OIE, 2008). Serum samples collected randomly from clinical cases in each outbreak were used for the test. The nature of the disease including the clinical signs, proportion of infection, mortalities and gross lesions were observed and 
recorded.The cheesy materialsand ocular swabs were collected during clinical and examination and subjected to bacteriological examination.

\section{Outbreaks \\ Outbreak I}

An outbreak of a combination of dry and wet forms of fowl pox occurred in a batch of 250 white cockerels that was introduced in a pen at the age of 5 weeks. The disease occurred 3 weeks after introduction. The birds were not vaccinated against the disease. The clinical signs observed in this outbreak were typical of both cutaneous and diphtheritic forms of fowl pox. There was reduced feed and water consumption. The birds had nodular lesions on the comb, wattle, eyelids, which started with few birds and gradually spread to more birds. There were no lesions on the legs. Morbidity (proportion infected) was about $85 \%$ while mortality was $40 \%$. Disease in the cockerels lasted for 4 weeks.

\section{Outbreak II}

This occurred in a batch of 1800 brown layers. They were introduced in the same pen that housed the cockerels 3 months after their removal. They were introduced at the age of 16 weeks. Before their introduction, the pen was washed with water and detergent. The birds were not vaccinated against fowl pox. Other pens in the same farm housed other batches of birds (layers and pullets), which were all vaccinated against the disease. No outbreak was noticed in these vaccinated groups. The unvaccinated group started laying eggs at the age of 18 weeks. Severe outbreak occurred about 3 weeks into lay. Live attenuated vaccine was administeredlate at 17 days after the onset of the disease. The condition was also managed with Neoceryl ${ }^{\circledR}$, an antibiotic preparations containing neomycin, streptomycin, colistin and vitamins.

As was observed in the previous outbreak in cockerel, the disease was typical of both cutaneous and diphtheritic forms of fowl pox. The first sign in the layers was reduced egg production. The production which was rising suddenly stopped and started declining.There was reduced feed and water consumption. The birds like in theprevious outbreak had nodular lesions on the combs, wattles, eyelids, which started with few birds and gradually spread to more birds. There were also no lesions on the legs. Morbidityin this outbreak was near $100 \%$ and mortality was about $50 \%$ while egg production dropped to $15 \%$ hen day production. A very important observation at advanced stages in this case was ocular discharges with swollen heads and eyes (Fig 1) which in some birds were unilateral and in some other ones were bilateral. This was observed latter in the infection and some of the nodules and scabs were seen to be falling off. The cutaneous lesions and accompanying discharges tend to stick the eyelids together thereby partially or completely occluding the eyes. In the layers, a whitish caseous or cheesy material could easily be expressed out from the swollen eyes (Fig 2). The cheesy materials examined conformed to the shape of the cornea i.e. an outer convex surface and inner concave surface resting on the cornea. Depending on when the material was removed, there were varying degrees of corneal opacity resulting in varying degrees of blindness. Thecaseousmaterials were collected for bacteriological examination.These caseous materials were not seen in the infection involving the white cockerels and layers in outbreak III.

Some moribund and dead birds were submitted for post mortem (PM) examination at the Department of Veterinary Pathology and Microbiology, University of Nigeria, Nsukka. The PM lesions observed in all the cases were similar. Cutaneous lesions were seen in all stages of development i.e. papule`s, vesicles, pustules, and scabs.The scabs appeared as rough reddish brown to black lesions. Examination of the membranes showed diphtheritic lessons in the mouth and the digestive tract which when removed, resulted in sore ulcers. Soiled vent and enteritis were seen in some cases. No gross lesion was seen in the internal organs. The disease lasted for more than two months in this flock.

\section{Outbreak III}

The pen that housed the birds in the previous two outbreaks was washed thoroughly with water and detergent and left empty for another 3 months. Another batch of 1500 brown pullets at 16 weeks of age was introduced into the pen. These birds were vaccinated against fowl pox at the age of 6 weeks. The birds started laying eggs at the age of 18 weeks. The birds came down with fowl pox6 weeks after introduction in the laying pen. The disease was very mild consisting of the cutaneous form only. About $3.5 \%$ of the birds were affected and no mortality due to this disease was recorded. In the affected birds, only few cutaneous nodules were observed on the combs and wattles. There was no effect on egg production as there was steady rise in hen day production until peak was reached. The lesions disappeared within 10 days.

Agar gel inmunodiffusion (AGID) test.Serum samples collected from birds in each outbreak were subjected to AGID test following the procedures described in OIE manual (OIE, 2008). Briefly, commercially available agar rose was used as the gel-diffusion medium. The gel was prepared in AGID plates and wells were cut using 
template. Purified fowl pox viral antigens were placed in the central wells and the test sera were placed in the peripheral wells.Positive and negative controls were also included. The plates were incubated at room temperature and examined after 24 and 48 hours. Development of precipitin lines showed positive results.

Bacteriological examination.The cheesy material and the ocular swabs which were collected using strict aseptic techniques were subjected to bacteriological examination as outlined in Cappucino and Sherman, (2011). The specimens were plated on Blood and MacConkey agar plates by the streak method. The surface and the matrix of the cheesy materials were plated separately. The plates were incubated at $37^{\circ} \mathrm{C}$ for $24-48$ hours. The plates were read and results recorded. The discrete colonies were sub cultured in fresh Blood and Mackonkey agar plates to obtain pure cultures. The colonies were Gram stained, examined under oil immersion and results recorded.

\section{Results}

The serum samples examined for antibodies against fowl pox virus using AGID test showed precipitin line in the gel indicating positive result. The bacteriological examination did not reveal any bacteria in the matrix of the cheesy material. However, the surfaces of the cheesy material and the ocular discharges revealed a mixed growth of two organisms. One organism was medium sized gray colonies which were Gram positivecocci in clusters. These were identified as Staphylococcus spp. The other organism gave a medium sized lactose fermenting colonies which were Gram negative rods.These were identified as Escherichia coli.

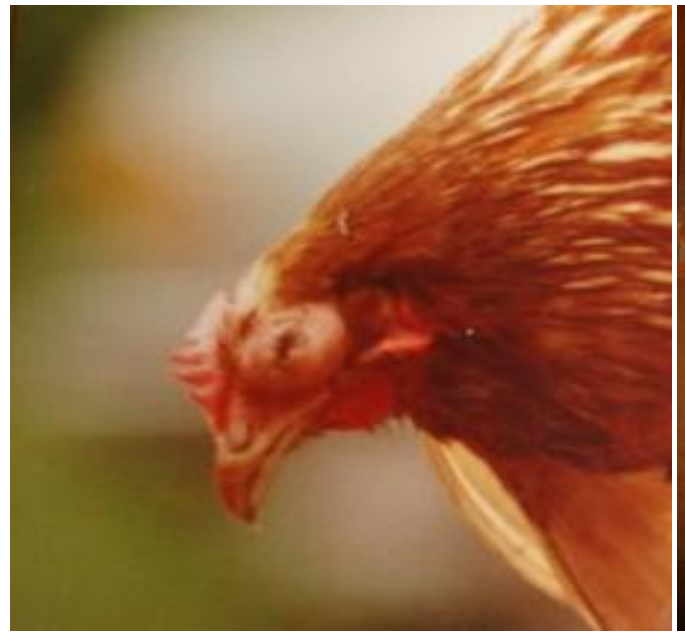

a

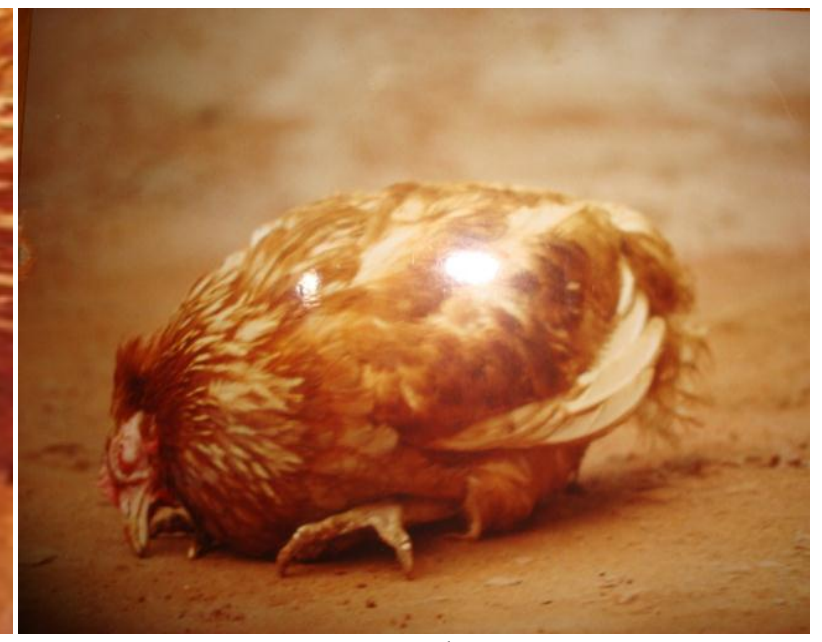

b

Figure 1:a). Swollen or distended eye in chronic fowl pox as seen in outbreak II. b).An infected layer showing emaciation, prostration and distended eye.



Figure 1: Cheesy materials expressed from the infected and distended eyes of a chicken in outbreak II 
Table 1: Clinical parameters as recorded for chickens in the three outbreaks.

\begin{tabular}{|c|c|c|c|c|c|c|c|c|c|c|}
\hline $\begin{array}{l}\text { Outbreak } \\
\text { s }\end{array}$ & $\begin{array}{l}\text { No of } \\
\text { birds } \\
\text { involve } \\
d\end{array}$ & $\begin{array}{l}\text { Vaccination } \\
\text { against FP }\end{array}$ & $\begin{array}{l}\text { Latent } \\
\text { period } \\
\text { before } \\
\text { outbreak }\end{array}$ & $\begin{array}{l}\text { Presenc } \\
\mathrm{e} \quad \text { of } \\
\text { clinical } \\
\text { signs }\end{array}$ & $\begin{array}{l}\text { Percentage } \\
\text { infectivity }\end{array}$ & $\begin{array}{l}\text { Percentage } \\
\text { mortality }\end{array}$ & $\begin{array}{l}\text { Form of } \\
\text { disease }\end{array}$ & $\begin{array}{l}\text { Percentage } \\
\text { reduction } \\
\text { in egg } \\
\text { production }\end{array}$ & $\begin{array}{l}\text { Presence } \\
\text { of cheesy } \\
\text { materials }\end{array}$ & $\begin{array}{l}\text { Duratio } \\
n \quad \text { of } \\
\text { disease }\end{array}$ \\
\hline I & 250 & $\mathrm{NO}$ & 3 week & Yes & 85 & 40 & $\begin{array}{l}\text { Cutaneous } \\
\text { and } \\
\text { Diphtheritic }\end{array}$ & $=$ & $=$ & 4 weeks \\
\hline II & 1800 & $\mathrm{NO}$ & 5 weeks & Yes & 100 & 50 & $\begin{array}{l}\text { Cutaneous } \\
\text { and } \\
\text { Diphtheritic }\end{array}$ & 15 & + & 8 weeks \\
\hline III & 1500 & YES & 6 weeks & no & 3.5 & 0 & Cutaneous & None & $=$ & 10 days \\
\hline
\end{tabular}

\section{Discussion}

The clinical signs, gross lesions and laboratory investigations in the outbreaks confirm all the outbreaks to be fowl pox. Most of the signs and lesions observed were similar to that described for the disease (Tripathy and Reed, 2003). The ubiquitous nature of the disease has also been highlighted (Mocket, 1996; Adebajoet al., 2012). Andrews et al. (1978) noted that poxviruses are resistant to desiccation and can remain in dried scabs for months or even years and difficult to clean from the environment. This may be responsible for the recurring infections seen here, even after cleaning and leaving the pen empty for three months. Severe disease outbreak was seen in each unvaccinated flock introduced into the pen even after washing and leaving the empty for few months. There was also a mild disease in the vaccinated flock introduced into the pen. This supports the earlier reports on the abilities of the virus to survive in the environment for a long time. In addition to the resistance of the virus, other important epidemiological factors in the transmission of the virus may also contribute to the recurring outbreak. According to DNR, (2011) transmission of the avian pox virus can occur in a number of ways. The disease can spread via mechanical vectors, primarily by some species of mosquitoes and this occurs when the mosquito feeds on infected birds passing through the viraemic phase or on virus-laden secretions from a pox lesion and then feeds on uninfected birds. It has been noted that mosquitoes can harbour and transmit the virus for a month or longer after feeding on an infected bird (Proctor and Owens, 2000; DNR, 2011). Some other biting and sucking flies can also transmit pox virus (Medina et al., 2004; Adebajoet al., 2012). The work showed a period of $3-6$ weeks between introduction and outbreak of infection. This period probably represents the period between contact of the bird with the virus in the environment and the incubation period. This period varied among the outbreaks and the period before contact and picking of the virus in the environment will depend on chance. The incubation period may also have varied. The incubation period in fowl pox infection has been reported to vary from $4-10$ days (Dinev, 2010).

Transmission can also occur directly by direct contact between infected and susceptible birds. The virus is transmitted through abraded or broken skin or the conjunctiva or through fighting. Transmission can also occur through ingestion when food and water or through inhalation of pox virus infected dander, feather debris and air-borne particles.

As noted in this study both forms were seen in the severe outbreaks. According to Afonsoet al. (2000), the form are dependent on the routes of infection. The authors noted that the most common, the cutaneous form, occurs following infection by biting arthropods that serve as mechanical vectors for viral transmission and characterized by an inflammatory process with hyperplasia of the epidermis and feather follicles, scab formation, and desquamation of the degenerated epithelium. The second, or diphtheritic, form involves droplet infection of the mucous membranes of the mouth, the pharynx, the larynx, and sometimes the trachea. The findings here confirm the reports of Buller and Palumbo (1991) and that of Tripathy and Reeds, (2003) that both forms can occur in an outbreak. Therefore, it is possible that all the routes of infection were involved.

An uncommon and possibly unusual, but notable pathological lesion was the presence of cheesy materials in the eyes of many infected layers. When cultured the matrix of the cheesy yielded no bacteria while the surfaces and the discharges yielded Staphylococcal spp and Escherichia coli.Mockett (1996) reported ocular discharges in fowl pox outbreak. Dinev, (2010), reported that frequently, the conjuctival mucosa becomes injured by the pox virus and this will serve as an entrance door for additional bacterial contamination by Staphylococcus aureus and Escherichia coli. In the present report the discharges remained in the eye and became cheesy conforming to the shape of the cornea and different degrees of damage were seen in the cornea. This has not been reported as a common sign of fowl pox in Nigeria. This lesion was not seen in the young cockerel. The absence of bacteria in the matrix of the cheesy material may be an indication that this may be virus induced and possibly in combination with the bacterial organisms. It was also possible that the matrix was devoid of adequate biochemical and nutritional requirements for the growth and survival of the bacteria. The presence of enteritis and soiled vent may suggest possible intestinal involvement and bacterial complication in the gastrointestinal tract.. 
Fowl pox is a disease of global economic importance (Winterfield and Hitchner, 1985). Fowl pox vaccine is used in all categories of poultry in Nigeria (Odoyaet al., 2006). The effectiveness of vaccinations against the disease is very high. In Nigeria, many sporadic outbreaks have occurred due to ignorance on the part of the farmers resulting in non vaccination, improper vaccine storage, and improper administration of the vaccine. The mild disease seen in the last outbreak in the vaccinated birds points to the effectiveness of the vaccines in controlling the infection. The circulating antibodies and the specific cellular responses must have played a vital role in curtailing the infection. There was no reduction in feed and water consumption and there was also no reduction in egg production. Therefore, the vaccine effectively controlled the infection in the vaccinated birds when compared with the unvaccinated birds.

\section{Conclusion}

These investigations show that fowl pox is still an important disease in Nigeria with the abilities to persist in the environment causing recurring outbreaks in unprotected chickens. It can lead to significant economic losses due to mortalities associated with the severe forms of the disease. It also identified a peculiar lesion associated with the disease in advanced stages of the disease. The tendencies for the disease to linger in an affected flock were also pointed out. It also emphasized the need to institute adequate biosecurity measures in the control of the disease. Birds should be vaccinated early in life and where possible layers may be vaccinated again at point of lay especially in farms that have witnessed or are having outbreaks. Cleaning of pens after any outbreak should be thorough with disinfectants. Since there is no satisfactory or specific treatment for birds infected with avian poxviruses, prevention and control of the disease by good hygiene and adequate vaccinations are indispensible.

\section{References}

[1]. Adebajo, M. C., Ademola, S. I., and Oluwaseum, A. 2012. Seroprevalence of fowl pox antibodies in indigenous chickens in Jos North and South Council Areas of Plateau State, Nigeria: implication for vector vaccine. ISRN. Veterinary Science. 154971: $1-4$.

[2]. $\quad$ Afonso, C. L., Tulman, E. R., Lu, Z., Zsak, L., Kutish, G. F., and Rock, D. L. 2000. The genome of fowl pox virus. Journal of Virology.74: $3815-3831$.

[3]. Andrews, C., Pereinra, H.G., and Wildy, P. 1978. Viruses of Vertebrates, $4^{\text {th }}$ ed. BailliereTindall, London pp 356-389.

[4]. Ariyoshi, R., Takase, K., Matsuura, Y., Deguchi, K., Ginnaga, A., Fujikawa, H. 2003. Vaccination against fowlpox virus via drinking water. Journal of Veterinary Medical Science 65(10): 1127-1130.

[5]. Buller, R.M. and Palumbo, G.J. 1991. Poxvirus pathogenesis. Microbiology Review.55: 80-122.

[6]. Cappucino, J. G., and Sherman, N. (2011). Microbiology: A Laboratory Manual. $9^{\text {th }}$ Edition. Benjamin Cummings, Pearson. Boston. $1-29$.

[7]. Chambers, A. E., Dixon, M. M., and Harvey, S. P. 2009. Studies of the suitability of fowl pox as a decontamination and thermal stability simulant for variola major. International Journal of Microbiology. $1-9$

[8]. Dinev, I. 2010. Diseases of Poultry. A Colour Atlas. $2^{\text {nd }}$ Edition. Pp $78-102$.

[9]. DNR. (2011). Avian pox. In: Wildlife Diseases. Michigan Wildlife Disease Manual. Michigan Department of Natural Resources.

[10]. Fauquet, C. M., Mayo, M. A., Maniloff, J., Desselberger, U. and Ball, L. A. 2005. Virus Taxonomy: VIII ${ }^{\text {th }}$ Report of the International Committee on Taxonomy of Viruses. Technical Report. Elsevier Academic Press. New York. USA.

[11]. Hsieh, Y. C., Chen, S. H., Wang, C. W., Lee, Y. F., Chung, W. C., Tsai, M. C., Chang, T. C., Lien, Y. Y., Tsai, S. S. 2005. Unusual pox lesions found in Chinese jungle mynahs (Acridotherescristatellus). Avian Pathology: 34(5): 415-417.

[12]. Medina, F. M., Ramirez, G. A., and Hernandez, A. 2004. Avian pox in white-tailed laurel-pigeons from the Canary Islands. Journal of Wildlife Diseases.40(2): 351 - 355.

[13]. Mockett, A. P. A. 1996. Fowl pox and other avian poxes. In; Poultry Disease, $4^{\text {th }}$ edition F.T.W. Jordan and M. Pattison (eds) pp $166-172$

[14]. Nagu, E., Maeda-Machangu, A., Krell, P. and Derbshire, J. 1990. Vaccination of 1-day-old chicks with fowl pox virus by the aerosol, drinking water or cutaneous routes. Avian Diseases.34: 677-682.

[15]. Odoya, E. M., Abegunde, A., Agyogbo, B. G., Omotainse, S. O., Gwakat, E., and Okpara, U. G. 2006. Outbreak of turkey pox disease in fowl pox vaccinated poults in Vom, Plateau State of Nigeria. African Journal of Clinical and Experimental Microbiology.7(2): $136-138$.

[16]. OIE. 2008. Fowl pox. In: Office International des Epizooties Terrestrial Manual. Pp $531-537$.

[17]. Okwor, E. C., Eze, D. C., and Agbo, I. C. 2012. The effects of vaccination, antibiotic and vitamin therapy on some clinical parameters associated with natural outbreak of fowl pox in chickens. Journal of Veterinary Medicine and Animal Health. 4(9): 136 - 139.

[18]. Pledger, A 2005. Avian pox virus infection in a mourning dove. Canadian Veterinary Journal. 46:1143-1145.

[19]. Proctor, H. and Owens, I. 2000. Mites and birds: diversity, parasitism and coevolution. Trends in Ecology and Evolution.15(9): 358 - 364

[20]. Silva, P. S. da., Batinga, T. B. de., Sales, T. S., Herval, E. F. G., Ramos, I., Maia, P. C. C., and Fernandes, L. M. B. 2009. Fowlpox: identification and adoption of prophylactic measures in backyard chicken in Bahia, Brazil. RevistaBrasileira de CienciaAvicola.11(2): 115 119.

[21]. Singh, P., Kim, T. J., and Tripathy, D. N., 2000. Re-emerging fowl pox: evaluation of isolates from vaccinated flocks. Avian Pathology.29(5): $449-455$.

[22]. Todese, T., Potter, A. E., Fitzgerald, S., and Reed, W. M. 2007. Concurrent infection in chickens with fowl pox and infectious laryngotracheitis virus as detected by immunohistochemistry and a multiplex polymerase chain reaction technique. Avian Diseases.51(3): $719-724$.

[23]. Tripathy, D.N. 1993. Avipox Viruses. In: J. B. McFeran and M.S. McNulty (eds). Virus Infections of Vertebrates Vol. 4 Virus infections of birds. Elsevier Science, Netherlands pp 5-15.

[24]. Tripathy, D.N. and Reed, W.M. 2003. Pox. In: Y. M Saif. Diseases of Poultry. (ed) $10^{\text {th }}$ edition IOWA State University Press pp 253 - 269.

[25]. Winterfield, R.W. and Hitchner, S.B. 1985. The response of chickens to vaccination with different concentration of pigeon pox and fowl pox viruses. Avian Diseases.9: 237-241. 